\title{
THE METHOD OF PREDICTING THE EXTENT OF CHANGES IN THE PERFORMANCE CHARACTERISTICS OF RESIDENTIAL BUILDINGS
}

\section{B. NOWOGOŃSKA ${ }^{1}$}

\begin{abstract}
Accordingly to recommendations set out by standards, degradation curves which will serve as a tool facilitating decision-making regarding renovation works ought to be developed. The article presents the proposal of a model for predicting the aging of a residential building. The proposed PRRD (Prediction of Reliability According to Rayleigh Distribution) model determines the performance characteristics of a building over the full period of its use. PRRD accounts for the life spans of individual building components. Additionally introduced in the model were supplements accounting for the intensity of changes in the building and its surroundings. The developed method of the non-linear degradation process of a building accounts for the role and weights of individual building components as well as the intensity of significant factors influencing the aging process. The presented methodology of the description of changes in the performance characteristics over the course of using a building will be a diagnostic process of predicting the technical state of a building. The proposed predictions can serve as the basis for making the right strategic decisions when planning renovation works in residential buildings.
\end{abstract}

Keywords: performance characteristics, planning service life PSL, technical condition

\section{INTRODUCTION}

In order to ensure an adequate technical state of a building over the course of its use, familiarity with the building aging process is useful. Attempts are being made to describe the building degradation process using, e.g. neuron networks [1], fuzzy sets [2] or stochastic processes [3]. At the same time,

\footnotetext{
${ }^{1}$ Assoc. Prof. PhD. Eng., University of Zielona Góra, Faculty of Civil Engineering, Architecture and Environmental Engineering, ul. Szafrana 1, 65-516 Zielona Góra, Poland, e-mail: b.nowogonska@ib.uz.zgora.pl
} 
along with the aging process over the course of using a building are the ever-increasing civilizational needs of the inhabitants [4-7]. A prediction of the aging process of a building is useful when making decisions regarding renovation undertakings over the course of building maintenance [8-10]. In accordance with the standard [11-14], the prediction of the degradation of a building ought to rely on predicting changes in its operational properties. A performance characteristics - time relationship ought to be developed, as a non-linear function of time.

\section{FACTORS INFLUENCING PERFORMANCE CHARACTERISTICS}

In the aging process of a building, factors influencing its degradation occur. These factors can occur at various changing intensities. According to standards [11-14], factors influencing the operational properties of a building and their components are grouped into factors affecting it from the outside, from the atmosphere or of a natural origin, or caused by human activity, as well as those acting inside the building - caused by use or being the consequence of a construction design.

When predicting changes in the performance characteristics of a building [11-14], three problems ought to be accounted for: factors responsible for degradation, consequences of changes in the intensity of factors and consequences of the effects of a combination of these factors.

Factors influencing the degradation of a building are destructive mechanical, electromagnetic, thermal, chemical and biological activities. Familiarity with the anticipated intensity of the effects of a factor and determining its minimal and maximal values will help to determine the prediction of damages.

Over the course of using residential buildings, factors influencing the aging process very rarely occur individually; they most often work together, sometimes in dependant systems. The predicted service life ought to account for the most unfavourable of situations, i.e., the simultaneous effects of all factors. A difficult task, however, is determining the prediction of the intensity with which these factor act, combinations of intensity and the effects of their action. In accordance with standards [1114] only the most significant factors can be accounted for when predicting the aging process. An assessment of the effects of significant factors in an individual manner as well as in combination with other factors ought to be carried out. Accounting for degradation caused by various significant factors, in residential buildings these factors result in natural wear over the course of their use. 


\section{Planning Service Life}

Planning the service life (Service Life Planning) of the building is strictly connected with the problem of predicting the service life of its components. The standard [14] gives the coefficient method used to predict the service life SLP. This method relies on determining the estimated service life (ELS) based on the modification of the reference service life (RSL) by accounting for differences between the conditions accepted in the project and a reference set of in-use conditions.

$$
\mathrm{ESL}=\mathrm{RSL} \times \mathrm{A} \times \mathrm{B} \times \mathrm{c} \times \mathrm{D} \times \mathrm{E} \times \mathrm{F} \times \mathrm{G}
$$

where:

A, B, C, D, E, F, G - coefficients describing differences between conditions.

Coefficient A describes the quality of the building components, coefficient B - design level, coefficient $\mathrm{C}$ - construction work execution level, coefficient $\mathrm{D}$ - indoor environment, coefficient $\mathrm{E}$ - outdoor environment, coefficient $\mathrm{F}$ - actual usage conditions, and coefficient $\mathrm{G}$ - maintenance level. Coefficients with a value of less than 1.0 reduce the estimated service time, while coefficients with a value of greater than 1.0 cause its increase. The appropriate choice of values for modifying coefficient $\mathrm{A}-\mathrm{G}$ depends on the differences between the reference conditions assumed in the design and reference usage conditions. The influence of the quality attributes of a building on the service period is accounted for by coefficients A, B and C (quality level, design and execution), the influence of the environment - coefficients D and E (indoor, e.g., ventilation; and outdoor, e.g. pollution, atmospheric conditions) as well as the influence of the usage conditions by coefficients $F$ and $G$ (conditions during the service period, thus categories of usage and type of maintenance, e.g. frequency of refurbishment). In accordance with the standards [11-14], the degradation factors as well as mechanisms of degradation, as a result of which factors may induce changes in the performance characteristics of a building, ought to be determined, as well as the measurable effects of degradation, and methods of verifying these studies ought to be developed.

Currently, there is a lack of analyses regarding the prediction of RSL of building structures and studies on the changes in the performance characteristics of building structures are only now being carried out. 


\section{COURSE OF CHANGES IN THE PERFORMANCE CHARACTERISTICS IN THE FUNCTION OF TIME ACCORDING TO THE PRRD MODEL}

One of the proposals for predicting the aging process is the PRRD method. Over the course of the service life of residential buildings, the performance characteristics of a building and its individual components decrease with time. In accordance with requirements set out by standards [11-14], a program for the exposure of aging accounting for the most significant degradation mechanisms ought to be developed. A mathematical model for the distribution of the time of the proper performance of technical objects as well as the durability of goods applied is the Weibull distribution. In accordance with the assumptions of this distribution, the $R_{0}(t)$ function, describing the course of the process of changes in the performance characteristics [3] in time $t$, takes on the general form of:

$$
R_{o}(\mathrm{t})=\exp \left(-(\beta \mathrm{t})^{\alpha}\right)
$$

The Weibull distribution is a class of distributions, and a particular case of the Weibull distribution is the exponential distribution. The exponential distribution is applied very often [15-18] to describe changes in the reliability of technical devices, however an exponential model of the reliability distribution does not appear in reality. In the exponential distribution, a large approximation is made, i.e. the negligible influence of wear processes. A characteristic feature for the exponential distribution is the constant intensiveness of damage over the entire service life of the object. Another particular of the Weibull distribution is the Rayleigh distribution [3, 15-18]. This distribution occurs when the wear of the structure over time is the main reason for failure. The choice of the Rayleigh distribution for modelling the aging process of buildings appears to be the most appropriate choice. Buildings undergo wear over the course of use, and the Rayleigh distribution is applied when the wear of the building increases along with the passing of time it is in use.

The function describing the course of changes in the service properties in time $t$ based on the Weibull distribution is expressed by the relationship (1.1). In the Rayleigh distribution, parameters $\alpha$ and $\beta$ are equal to:

$$
\alpha=2, \beta=\frac{1}{T}
$$


The proposed PRRD (Prediction of Reliability According to Rayleigh Distribution) model - of changes in the performance characteristics of the $i$-th building component based on the Rayleigh distribution is a description of the aging process of a component and building:

$$
\mathrm{R}_{\mathrm{i}}(\mathrm{t})=\exp \left(-\left(\frac{\mathrm{t}}{\mathrm{T}_{\mathrm{i}}}\right)^{2}\right)
$$

where:

$R_{i}(t)$ - changes is the performance characteristics of component $i$, t-service time, $T_{i}-$ lifespan of component $i$.

A building is made up of many inter-connected components. Every building component has a role. Elements which serve structural functions have the most important influence on the service life. Other auxiliary components influence the performance characteristics of a building to a lesser degree, and their influence results, above all, from the fact that damage to auxiliary elements can cause changes in the parameters of fundamental components. When indicating the performance characteristics of an entire building, which is a collection of components, the intensities of the influence of performance characteristics in the form of $A_{i}$ weights of individual components have been accounted for. Changes in the performance characteristics of a building $\mathrm{R}_{\mathrm{B}}(\mathrm{t})$ in time $t$ are specified by the relationship:

$$
\mathrm{R}_{\mathrm{B}}(\mathrm{t})=\sum_{\mathrm{i}=1}^{\mathrm{m}}\left[\mathrm{A}_{\mathrm{i}} \mathrm{R}_{\mathrm{i}}(\mathrm{t})\right]
$$

where:

$\mathrm{R}_{\mathrm{i}}(\mathrm{t})$ - changes in the performance characteristics of component $\mathrm{i}, \mathrm{A}_{\mathrm{i}}$ - weight of the $i$-th component, $i$ number of building component, $m$ - number of all components.

Figure 1 presents the predicted aging process in the form of the prediction of changes in the performance characteristics of residential buildings built using traditional technology. In this building, the load-bearing walls and partition walls are laid from solid brick, on cement-lime mortar; the rafter framing, ceilings and stairs, window frames and doors are wooden, the roof cover are ceramic tiles, and gas hook-ups as well as water-sewage pipes are from galvanized steel. 


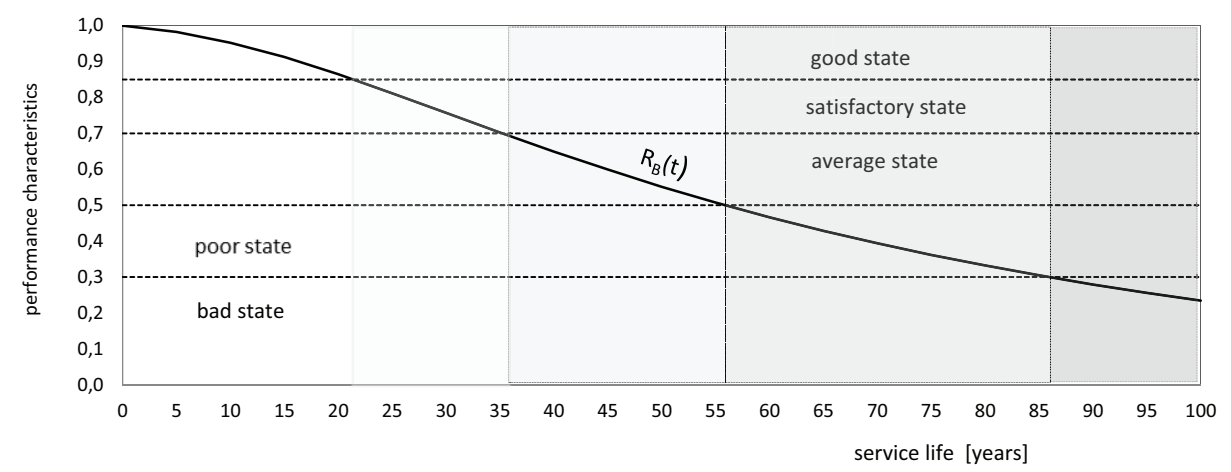

Fig. 1. Changes in the performance characteristics of the entire building $\mathrm{R}_{\mathrm{B}}(\mathrm{t})$ according to the PRRD model

In the picture, the borders of individual technical conditions were additionally indicated, determined by the category of technical conditions - good, satisfactory, average, poor, bad. The limit values of the technical states were assumed in accordance with the values corresponding to the levels of technical wear. The chart of changes in the performance characteristics of the building makes it possible to determine the time of achieving technical conditions by the building during its usage. Under the assumption of nonfeasance of refurbishment activities on the building, a good technical condition changes to satisfactory in the $22^{\text {nd }}$ year of use, average in the $35^{\text {th }}$ year of use, poor in the $55^{\text {th }}$ year of use, and finally bad in the $85^{\text {th }}$ year of use.

\section{PRRD MODEL ACCOUNTING FOR THE INTENSITY OF DEGRADATION FACTORS}

In the proposed PRRD model, the results of the assessment of the durability of building components which are available in technical literature were accounted for. The disabilities of building components are given in literature as ranges of periods which result from the different conditions concerning location, maintenance, variability in properties of materials, the level of workmanship, and the level of design. Taking into account the time ranges of the durability of building components in predicting changes in the performance characteristics of components, the estimated service life was determined, while coefficients A-G had already been accounted for in the form of the lifespans of building components.

For the proposed PRRD model, the changes in performance characteristics for minimum lifespans of each building component $\mathrm{R}_{\mathrm{i}}(\mathrm{t})_{\min }$ were calculated according to Formula (1.3), and next, in accordance 
with Formula (1.4), the function of changes in the performance characteristics of the entire building $\mathrm{R}_{\mathrm{B}}(\mathrm{t})_{\min }$ was determined for the entire building for minimal lifespans of individual building components.

The next stage was to indicate the functions of changes in the performance characteristics for maximum lifespans of individual component of the building as well as the entire building $R_{B}(t)_{\max }$.

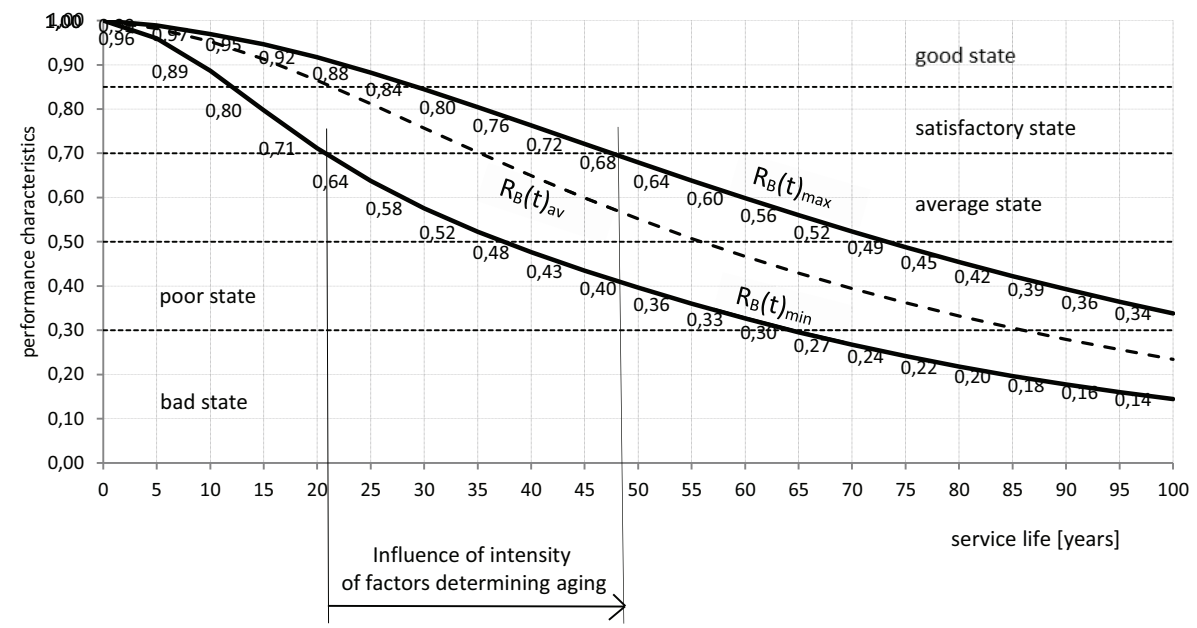

Fig. 2. Changes in the performance characteristics of buildings in the PRRD model accounting for the intensity of factors determining aging.

In Figure 2, the functions of changes in the performance characteristics of the entire building are presented accounting for the maximum and minimum durability periods of components. Material and structural solutions of a building such as that in Figure 1 were accepted for the analysis.

\section{CONCLUSIONS}

Predicting the aging process is essential over the course of the maintenance a residential building. In accordance with the standard recommendations, degradation curves of the building ought to be developed and changes in the planned service life presented. However, the problem remains unrecognized in many aspects. The lack of data indicates the need for studies and analyses connected with the topic. The predicted changes in the performance characteristics of residential buildings can be useful in making the right decisions when planning construction works. 


\section{REFERENCES}

1. P. Knyziak, "Estimating the Technical Deterioration of Large-Panel Residential Buildings Using Artificial Neural Networks", Procedia Engineering, 91, pp. 394-99, 2014.

2. E. Radziszewska-Zielina G. Śladowski, "Supporting the Selection of a Variant of the Adaptation of a Historical Building with the Use of Fuzzy Modelling and Structural Analysis”, Journal of Cultural Heritage Vol. 26, pp. 53-63, 2017.

3. B. Nowogońska, "The Life Cycle of a Building as a Technical Object", Periodica Polytechnica Civil Engineering, vol. 60 (3), pp. 331-336, 2016.

4. R. Bucoń, A. Sobotka, "Decision-making model for choosing residential building repair variants", Journal of Civil Engineering and Management 21 - 7, pp. 893-901, 2017.

5. A. Ostańska, "Evolution of spaces between buildings in polish mass housing estates in the eyes of the inhabitants," WMCAUS 2017, IOP Conf. Series: Materials Science and Engineering 245, 052044 Prague, Czechy, 2017.

6. E. Radziszewska-Zielina, G. Śladowski, M. Sibielak, "Planning the reconstruction of a historic building by using a fuzzy stochastic network", Automation in ol. Construction V84, pp. 242-257, 2017.

7. B. Nowogońska, J. Cibis, "Technical problems of residential construction”, WMCAUS 2017, IOP Conf. Series: Materials Science and Engineering, Vol. 245, 052042 Prague, Czechy, 2017.

8. A. Sobotka, A. Radziejowska, J. Czaja, "Tasks and Problems in the Buildings Demolition Works: A Case Study Archives of Civil Engineering vol. 61, 4, 2015.

9. J. Korentz, B. Nowogońska, "Assessment of the life cycle of masonry walls in residential buildings". Proceedings of the Environmental Challenges in Civil Engineering ECCE Opole, Polska, 2018, MATEC Web of Conferences, Vol. 174, 01025, Opole, Polska, 2018.

10. B. Nowogońska, "Model of the reliability prediction of masonry walls", Engineering Mechanics 2014 - 20th international conference Svratka, Czechy. Brno University of Technology, pp. 456 - 459, 2014.

11. PN-ISO 7162:1999 Usable requirements in construction. Content and layout of standards for the assessment of performance [in Polish].

12. PN-ISO 7162:1999 Service Requirements in Construction. Content and Form of Standards Regarding the Assessment of Performance Characteristics [in Polish].

13. PN-ISO 15686005 Buildings and Structures. Planning Service Life. Part 2. Procedures Connected with Predicting Service Life [in Polish].

14. PN-ISO 15686005 Buildings and Structures. Planning Service Life. Part 7. Performance evaluation for feedback of service life data from practice [in Polish].

15. G. Cordeiro, M. Ortega, A. Lemonte., "The Exponential-Weibull Lifetime Distribution”, Journal of Statistical Computation and Simulation 84 (12), pp. 1-15, 2013.

16. R. E. Walpole, R.H. Myers, "Probability and Statistics for Engineers and Scientists", Macmillan Publishing Company, London 1985.

17. B. Nowogonska, "Preventive services of residential buildings according to the pareto principle", IOP Conf. Series: Materials Science and Engineering 471, 112034, 2019.

18. A. Khelassi, D. Theilliol, P. Weber, "Reconfigurability Analysis for Reliable Fault-Tolerant Control Design", International Journal of Applied Mathematics and Computer Science 21 (3), pp. 431-9, 2011.

\section{LIST OF FIGURES:}

Fig. 1. Changes in the performance characteristics of the entire building $R_{B}(t)$ according to the PRRD model

Rys. 1. Zmiany właściwości użytkowych całego budynku $R_{B}(t)$ wg modelu PRRD

Fig. 2. Changes in the performance characteristics of buildings in the PRRD model accounting for the intensity of factors determining aging

Rys. 2. Zmiany właściwości użytkowych budynku w modelu PRRD z uwzględnieniem intensywności czynników determinujących starzenie 


\section{METODA PRZEWIDYWANIA ZMIAN WŁAŚCIWOŚCI UŻYTKOWYCH BUDYNKÓW MIESZKALNYCH}

Keywords: właściwości użytkowe, planowanie okresu użytkowania, stan techniczny

\section{SUMMARY:}

Zgodnie z zaleceniami normowymi należy opracować krzywe degradacji, które posłużą za narzędzia wspomagające podejmowanie decyzji remontowych. W artykule przedstawiona jest propozycja modelu prognozy starzenia budynku mieszkalnego. Zaproponowany model PRRD (Prediction of Reliability acording to Rayleigh Distribution) określa zmiany właściwości użytkowych budynku w pełnym okresie jego użytkowania. PRRD uwzględnia okresy trwałości poszczególnych elementów składowych budynku. Do modelu dodatkowo wprowadzone zostały uzupełnienia uwzględniające intensywność zmian w obiekcie i w jego otoczeniu. Opracowana metoda nieliniowego procesu degradacji budynku uwzględnia rolę i wagę poszczególnych elementów składowych budynku oraz intensywność czynników istotnych wpływających na proces starzenia.

Normy dotyczące planowania okresu użytkowania grupują czynniki wpływające na degradację budynku i jego części składowych na działające spoza budynku: $\mathrm{z}$ atmosfery lub podłoża pochodzenia naturalnego, spowodowane działaniem człowieka oraz czynniki działające wewnątrz budynku - wywołane użytkowaniem lub będące konsekwencją projektu budowalnego. Podczas użytkowania budynków mieszkalnych czynniki wpływające na proces starzenia bardzo rzadko występują pojedynczo, najczęściej działają łącznie, niekiedy w układach zależnych. Prognozowany okres użytkowania powinien uwzględniać sytuację najbardziej niekorzystną, czyli jednoczesne działanie wszystkich czynników. Trudnym zadaniem jest jednak określenie prognozy zmian intensywności działania tych czynników, kombinacji intensywności oraz skutków ich działania. Zgodnie z normą można uwzględnić tylko najbardziej istotne czynniki w prognozowaniu procesu starzenia.

W zaproponowanej metodzie PRRD uwzględnione zostały wyniki oceny trwałości elementów składowych budynku dostępne w literaturze technicznej. Trwałości elementów budynku podawane są w przedziałach okresów, które to wynikają ze z różniących się warunków lokalizacji, utrzymania, zmienności cech materiałów, poziomu wykonawstwa, poziomu projektowania. Uwzględniając przedziały czasowe okresów trwałości elementów budynku w prognozowaniu zmian właściwości użytkowych elementów został określony szacowany okres użytkowania.

Prognozowanie procesu starzenia jest niezbędne podczas utrzymania budynku mieszkalnego, jednak problem jest w wielu aspektach nierozpoznany. Brak danych wskazuje na potrzebę badań i analiz związanych z tą tematyką. Prognozowane zmiany właściwości użytkowych budynków mieszkalnych mogą być pomocne w podejmowaniu prawidłowych decyzji w planowaniu prac budowlanych.

Received 02.04.2019

Revised 15.04.2019 